\title{
V12 - COQUELUCHE NO BRASIL: CARACTERIZAÇÃO DE LINHAGEM DE Bordetella pertussis PÓS-VACINAL
}

Diego D. Cambuy, Fernanda Freitas, Érica M. Scheidegger, Érica Fonseca, Flávio Rocha da Silva, Ana Carolina P. Vicente

Laboratório de Genética Molecular de Microroganismos

Instituto Oswlado Cruz

Coqueluche é uma infecção do trato respiratório que tem como principal agente etiológico a bactéria Bordetella pertussis. A imunoprevenção é feita, desde os anos 50, com vacinas de células inativadas ou acelulares compostas por proteínas imunogênicas: toxina pertussis, pertactina e fímbrias. Esta é a doença imunoprevinível mais comum no ocidente onde tem sido observado um substancial aumento de casos nos últimos anos. Diferenças entre isolados de $B$. pertussis do período pré e pós-vacinal foram observadas em diversos países com alta cobertura vacinal. Estas diferenças estão presentes em algumas das proteínas imunogênicas, o que poderia ter como consequência a diminuição ou perda da eficácia da vacina. No Brasil, surtos de coqueluche vem acontecendo nos últimos anos em todos os estados que poderiam ser determinados por falta de cobertura vacinal e/ou circulação de novas linhagens do patógeno.

Objetivos: Caracterização genética de isolados de B. pertussis do Brasil, considerando genes de virulência, que codificam proteínas usadas na composição da vacina acelular, e genes do genoma estável.

Metodologia: Isolados de B. pertussis dos anos de 2008 e 2009 de surtos nos estados do Rio Grande do Sul e de Alagoas foram analisados por duas abordagens de MLST, uma baseada em genes de virulência e outra em genes housekeeping, para a determinação de sua relação clonal. Foi feito PCR e sequenciamento dos genes: $a d k$, fum $\mathrm{C}, t y r \mathrm{~B}, i c d$, pepA, pgm (genoma estável) e para os genes de virulência: ptx $\mathrm{P}$ (região promotora do gene da toxina), ptxA (toxina pertussis), prn (pertactina) e fim3 (fimbria sorogrupo 3).

Resultados: Ambas as abordagens de MLST revelaram a presença de um único perfil alélico e, portanto de uma única linhagem circulante nestas regiões do Brasil. Essa 
linhagem é caracterizada pelo perfil alélico ptxp3-ptxA1-prn2-fim3B, e ST 1, que é o mesmo da linhagem pós-vacinal prevalente em países com alta cobertura vacinal em todo o mundo. Este perfil é distinto daqueles presentes nas linhagens usadas para a produção de vacina, incluindo a produzida no Brasil, que é ptxp2-ptxA4-prn1-fim3A. Esses resultados demonstram que, também no Brasil, infecções por B. pertussis estão sendo determinadas por linhagem adaptada a um "ambiente vacinado". 